\title{
Assessment of Nutrient Dynamics Affected By Different Levels of Lime in a Mungbean Field of the Old Himalayan Piedmont Soil in Bangladesh
}

\author{
Md. Abdul Halim ${ }^{1}$, *Md. Noor-E-Alam Siddique, Bikash Chandra Sarker², \\ Md. Jahidul Islam ${ }^{3}$, Md. Faruq Hossain ${ }^{4}$ and Md. Kamaruzzaman ${ }^{5}$ \\ ${ }^{I}$ Senior Scientific Officer, Soil Resource Development Institute, Ministry of Agriculture, District Office, \\ Dinajpur-5200, Bangladesh. \\ *Md. Noor-E-AlamSiddique, Senior Scientific Officer, Soil Resources Development Institute \\ (SRDI), Ministry of Agriculture, District Office, Pabna-6600, Bangladesh. \\ ${ }^{2,3}$ Professor, Department of Agricultural Chemistry, Hajee Mohhammad Danesh Science and \\ Technology University (HSTU), Dinajpur. \\ ${ }^{4}$ Senior Scientific Officer, Soil Resource Development Institute, District Office, Rangamati. \\ ${ }^{5}$ Principal Scientific Officer, Soil Resources Development Institute, Regional Office, Rajshahi, Bangladesh.
}

\begin{abstract}
A study was conducted to evaluate the effect of liming in the Himalayan Piedmont acid soil of Bangladesh on nutrient dynamics under different levels of lime in mungbean (Vigna radiate) field followed by T. Aman (transplanted rice) cultivation, during the period of December 2010 to October 2011. Five levels of lime were applied, viz, $T_{1}$ : control, $T_{2}: 1.0, T_{3}: 1.5, T_{4}: 2.0, T_{5}: 2.5$, ton lime $a^{-1}$. The $p H$ of soils after liming was increased steadily with the increased rate of liming. The different treatments were showed up varying results where more plant nutrients became available by increasing the concentration of $K, C a, M g, N, P, S, B$, $\mathrm{Cu}$ and $\mathrm{Mn}$; and slight decreased in the concentration of $\mathrm{OM}, \mathrm{Fe}$ and $\mathrm{Zn}$ that make the soil environment favorable for plant growth.The changes of soil properties like $\mathrm{pH}, \mathrm{OM}$ and some plant nutrients availability were significantly increased due to application of lime resulted in increased summer mungbean yield. The number of pods plant ${ }^{-1}$, number of seeds pod ${ }^{-1}, 1000$ seeds weight and grain yield were significantly affected by liming. The treatment $T_{3}\left(1.5 t\right.$ lime $\left.\mathrm{ha}^{-1}\right)$ produced Mungbean grain yield of $1.6 \mathrm{t}$ ha $\mathrm{T}^{-1}$ respectively which was significantly greater than those found in $T_{1}, T_{2}, T_{4}$ and $T_{5}$ treatments. Thus, the application of 1.5 time $h a^{-1}$ is recommended for the cultivation of summer mungbean and the desired soil $p H(>6.5$ but $<7.0)$, which increased availability of nutrients in the study area.The study revealed that liming increases soil $p H$ as well as changes other chemical properties of soil, which is beneficial to sustain high yield and may be an important soil management tool for mungbean cultivation in acid piedmont soil in the North East Bangladesh where soil acidity is predominant.
\end{abstract}

Keywords: Acid soil, Lime, Old Himalayan Piedmont Soil, Mungbean, Nutrient Availability

\section{Introduction}

Nutrient availability in soil depends on $\mathrm{pH}$. Most plant nutrients are available in neutral soil having $\mathrm{pH}$ 6.6 to 7.4. Soil acidity is a major growth-limiting factor for plants inmany parts of the world (Adams, 1980). Almost half of the soils of Bangladesh have varying degrees of soil acidity, except some Gangetic alluvial soils, all soils of Bangladesh are acidic to neutral (FRG, 2005) having $\mathrm{pH} 4$ to 7 and are deficient of $\mathrm{Ca}$ and $\mathrm{Mg}$. About 1.4 million hectare of land under Himalayan piedmont soil (AEZ 1) characterized by low pH and rich of phosphorus (SRDI, 2008). But the crop production potential is limited in these area due to less availability of phosphorous and toxicity of aluminum. The injudicious extraction of plant nutrients by growing crops without proper replacement causes plant nutrient deficiency, soil organic matter depletion, increased toxicity and soil compaction (Karim et al, 2001). This leads to deterioration in soil physical, chemical and biological properties. The soils of North west part of Bangladesh are light textured, low in OM and strongly acidic to moderately acidic in nature, $\mathrm{pH}$ ranges from 4.5 to 5.5 (FRG, 2005). The status of available $\mathrm{P}, \mathrm{Ca}$ and $\mathrm{Mg}$ of these soils are low. Aluminum toxicity is responsible for poor yield in acid soils. The adverse effect of acid soils on plant growth is mainly related to the presence of aluminum, manganese and iron in toxic concentration and deficiency of phosphorus, calcium, magnesium and molybdenum (Arshadet al., 1997; Maschner, 1991 and Edmeades, et al., 1995). Soil acidity also inhibits biological nitrogen fixation, reduced nodulation and growth in legumes (Alva et al., 1987). While, the principle of liming is that when $\mathrm{pH}$ of the soil decreases below the optimum range for the growth of specific crop variety lime is needed (Ocampo, 2000). Liming on acid soil increases the availability of $\mathrm{P}, \mathrm{Ca}, \mathrm{Mg}$ and $\mathrm{Mo}$ and renders iron and manganese insoluble and harmless, increases fertilizer effectiveness and decreases plant diseases (Sahai, 1990). Thus, the crop may have a better nutrition and the crop 
may produce a good yield. In problem soils, i.e., acid soil, farmers are applying a large amount of fertilizers for their major crops like rice, wheat etc. but they do not get desired yield. Unless the soil $\mathrm{pH}$ is raised around neutrality, the availability of nutrient element will limit the growth of plant.

Mungbean (Vigna radiate) has small root systems but its root nodulation helps a portion of $\mathrm{N}$ nutrition. Liming in the area that supplies $\mathrm{Ca}$ might enhance root development and root nodulation. Thus, it helps water absorption by increased root growth and $\mathrm{N}$ nutrition by symbiosis. On the other hand, increased root growth supplies more organic matter to soil resulting more organic carbon in soil. Therefore, the hypothesis is that liming promotes root growth and root nodulation, and helps for better pulse production and deposit more $\mathrm{C}$ and $\mathrm{N}$ in soil. Pulses grow well in free $\mathrm{Ca}$ rich soil but soil of Old Himalayan Piedmont plain and Agroecological Zone-1 has low $\mathrm{Ca}$ and $\mathrm{Mg}$. Therefore, under such circumstances, proper application of lime as a commercial alternative and ecologically sound means of reducing external inputs by improving internal resources, which will increase the yield and quality of mungbean. So, the hypothesis is that the application of lime on crop field will improve the soil nutrient availability by increasing soil $\mathrm{pH}$, and will increases crop yield when it is practiced routinely at right time with recommended amounts.

Liming promotes the decomposition of organic matter by making condition more favorable for the growth of microorganisms. The bacteria that fixed nitrogen from the air both non-symbiotically and in the nodules of legumes are specially stimulated by the application of lime. The successful growth of most soil microorganisms depends upon lime that satisfactory biological activities cannot be expected if calcium and magnesium levels are low. Therefore, present work has been designed for the following objectives: (a) to know the soil nutrient content changes under different levels of liming during mungbean cultivation followed by $\mathrm{T}$. Aman, and (b) to evaluate the chemical properties of soils under liming condition, and (c) to find out the trend of fertility improvement after liming in piedmont soils.

\section{Materials and Method}

The experimental field is located at $25^{\circ} 38^{\prime} \mathrm{N}$ latitude and $88^{\circ} 41^{\prime} \mathrm{E}$ longitude at the Agricultural Farm of Hajee Mohammad Danesh Science and Technology University, Dinajpur-5200, Bangladesh during the period from December 2010 to April 2011. The Agro-Ecological Zone belongs to Old Himalayan Piedmont Plain. The soil series is Ranisankail, sandy loam textured, a member of Hyperthermic Aeric Haplaquepts under the order Inceptisols having only few horizons, developed under Aquic moisture regime and variable temperature conditions (UNDP and FAO, 1988). The soil is non-calcareous Brown Floodplain Soils, Piedmont alluvium parent material and moderately well drained. The study area posses sub-tropical climate; the rainfall is heavy during Kharif season (April to September) and scanty in Rabi season (October to March).

Experimental design and treatments: The experiment was laid out in a Randomized Complete Block Design. All the treatments were replicated three times with 5 treatments. There were altogether $15(5 \times 3)$ unit plots and each plot having the measurement of $3 \mathrm{~m} \times 2 \mathrm{~m}$. Inter-block and inter-plot spacing were $1 \mathrm{~m}$ and $0.7 \mathrm{~m}$, respectively. There were five different rates of lime application in Mungbean (BARI mug-6) as follows: $\mathrm{T}_{1}$ : Control, $\mathrm{T}_{2}: 1.0 \mathrm{t}$ lime ha ${ }^{-1}, \mathrm{~T}_{3}: 1.50 \mathrm{t}$ lime ha ${ }^{-1}, \mathrm{~T}_{4}: 2.0 \mathrm{t}$ lime ha ${ }^{-1}$ and $\mathrm{T}_{5}: 2.50 \mathrm{t}$ lime ha ${ }^{-1}$. The liming material had $15.5 \% \mathrm{Ca}$ and $6.5 \% \mathrm{Mg}$. The liming material was applied to the soil on 21 March 2011 during land preparation.

Fertilizer application: The total amount of urea, TSP, MOP, Gypsum and Boric acid were applied during final land preparation. Nitrogen was applied @ $22 \mathrm{~kg} \mathrm{ha}^{-1}$ from urea, P @ $5 \mathrm{~kg} \mathrm{ha}^{-1}$ from TSP, K@ $19 \mathrm{~kg} \mathrm{ha}^{-1}$ from MoP, S @ $10 \mathrm{~kg} \mathrm{ha}^{-1}$ from gypsum and B @ $1.05 \mathrm{~kg} \mathrm{ha}^{-1}$ from boric acid. All fertilizers were incorporated to soil by spading one day before sowing on 27 March 2011.

Soil and plant sampling, analysis and processing: The initial soil sample (before liming) was analyzed for both physical and chemical properties. Then after liming, seed sowing, growing stage and after crop harvest soils were analyzed for soil $\mathrm{pH}$, organic matter, total $\mathrm{N}$ and available $\mathrm{P}, \mathrm{K}, \mathrm{B}, \mathrm{Zn}, \mathrm{Ca}, \mathrm{Mg}, \mathrm{Fe}, \mathrm{Mn}$ and $\mathrm{Cu}$ contents, respectively. Before land preparation, a composite soil samples were collected randomly from 10 different spots of the whole field from a depth of $0-15 \mathrm{~cm}$ on 11 March 2011. Also three soil samples were collected from each block on the same day. After designing the experimental plots 24 composite soil samples were collected from each plot before liming. Then after liming, seed sowing, and growing stage and after crop harvest at every time composite soil samples from each plot were collected with a interval of about 30 days during 4 May to 13 October 2011. In these way a total number of twelve times soil samples were collected (total no. of samples were $1+24 \times 11=265)$ plot wise. While data were collected on the following yield and yield components for Number of pods plant ${ }^{-1}$, Number of seeds pod ${ }^{-1}, 1000$ seeds weight $(\mathrm{g})$ and Grain yield $\left(\mathrm{kg} \mathrm{ha}^{-1}\right)$

Soil textural analysis was done by hydrometer method (Buoyoucos, 1927). The textural class was determined following Marshall's triangular coordinate using USDA system. Soil pH was measured with the help of a glass electrode $\mathrm{pH}$ meter, the soil-water ratio being 1:2.5 (Jackson, 1962). Organic carbon of soil was 
determined titrimetrically by Walkley and Black method, with the oxidation of organic matter in presence of potassium dichromate and sulphuric acid, called wet oxidation method (Page et al., 1982). The amount of organic matter was calculated by multiplying the percent organic carbon with the van Bemmelen factor, 1.73 (Piper, 1950). Total N content in soil was determined by micro-Kjeldahl method. Available P content was extracted from soil extraction by-1) Olsen's Method for alkaline soil and 2) Bray and Kurtz method for acidic soil (Petersen (1999). The content of $\mathrm{Ca}$ and $\mathrm{Mg}$ was measured by atomic absorption spectrometer (AAS). Exchangeable K content of soil was measured from above extraction by flame photometer (Page et al., 1982). $\mathrm{Cu}$ and $\mathrm{Zn}$ were measured by AAS on undiluted soil extracts. Fe and $\mathrm{Mn}$ were measured by AAS on soil extracts diluted 1:10 or more with water maintaining the same concentration of soil extracting solution as in the standard solutions. Digestion and followed by absorbance was measured at $420 \mathrm{~nm}$ on a spectrophotometer for boron.

The collected data on different parameters analyzed using MSTAT-C developed by Russel (1986). The treatments means were compared by Least Significant Difference test (LSD) at 5\% level of significance.

\section{Soil pH}

\section{Results and Discussion}

The $\mathrm{pH}$ values of soil that were collected from the field at different times were increased steadily with the increased rates of lime application (Figure 1). The $\mathrm{pH}$ value of before liming was 5.61, 5.51, 5.44, 5.82 and 5.52 , respectively. Just after liming, $\mathrm{pH}$ of the tested soils were raised above 8.0 in all cases but declined to 5.61, 5.62, 6.27, 6.65 and 6.7 in treatment $\mathrm{T}_{1}, \mathrm{~T}_{2}, \mathrm{~T}_{3}, \mathrm{~T}_{4}$, and $\mathrm{T}_{5}$, receptivity, after $30 \mathrm{DAL}$. The increase in soil $\mathrm{pH}$ was due to available $\mathrm{Ca}$ and $\mathrm{Mg}$ in soil. On the other hand, comparing the average $\mathrm{pH}$ status of initial soil just after liming (JAL), the highest $\mathrm{pH}$ were at the initial stage of the experiment, but at 150th day it was decreased due to application of nitrogenous fertilizers in T. Aman crop on August 10, 2011. Because the urea fertilizer reacted with soil and produced excess hydrogen ion and increased acidity of soil. These finding was also in agreement with the observation of Rao et al., (1982) and Basak, (2010). A significant increase in $\mathrm{pH}$ was obtained with lime application and the better $\mathrm{pH}$ range was observed with treatment $\mathrm{T}_{5}$. Similar observations were also reported by Saltave et al., (2009) and Murali (1976), that pH of soil steeply increased during the first 30 days after liming, then soon it started to decrease with time until the end of 180 days of experiment.

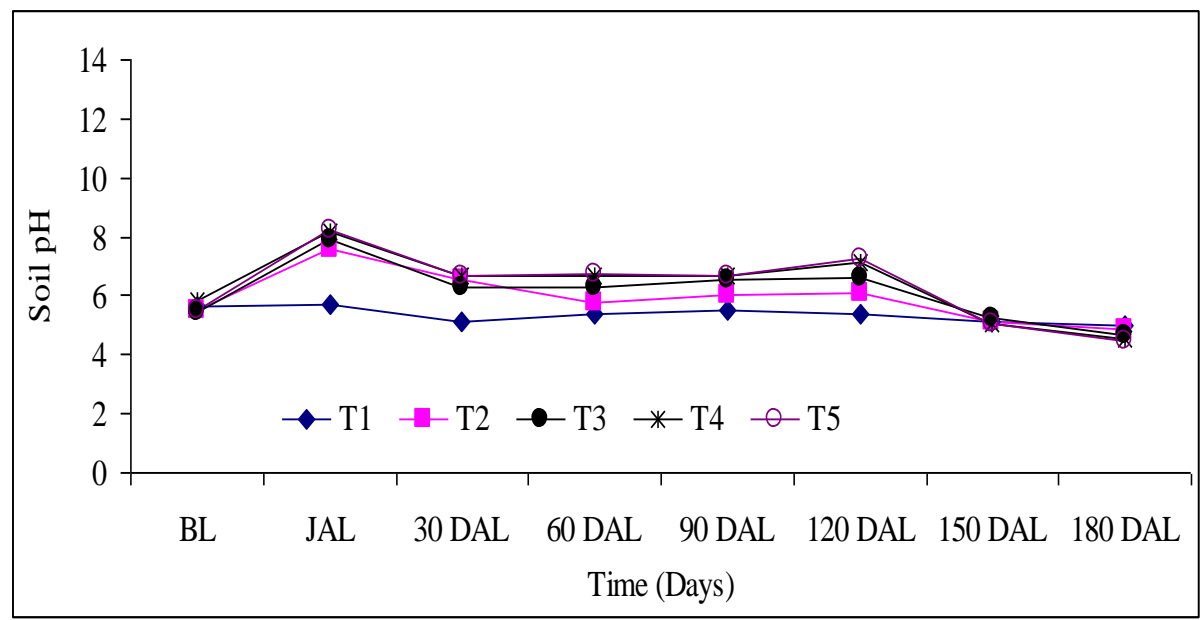

Figure 1. Soil pH under different levels of limes in summer mungbean followed by $\mathrm{T}$. aman field.

\section{Soil Organic Matter}

The average soil organic matter content in initial soil was slightly higher than soils collected after liming (Figure 2). This was due to the liming effect which increased $\mathrm{pH}$ of the initial acidic soil, as a result of higher microbial activities of the soil. These finding was also in agreement with the observation of Curtin et al., (1998) and Basak, (2010), as it was expected that liming brought an increase in microbial activity and a decreased in OM content in the soil. However, the effect of liming may vary with time and environmental condition such as soil temperature and moisture as reported by Kreutzer (1995). Similar observations were also reported by Renato et al., (2003). Soil textural properties like sandy loam soil could be also a possible cause for the decreased organic matter in the soil of experimental site. 


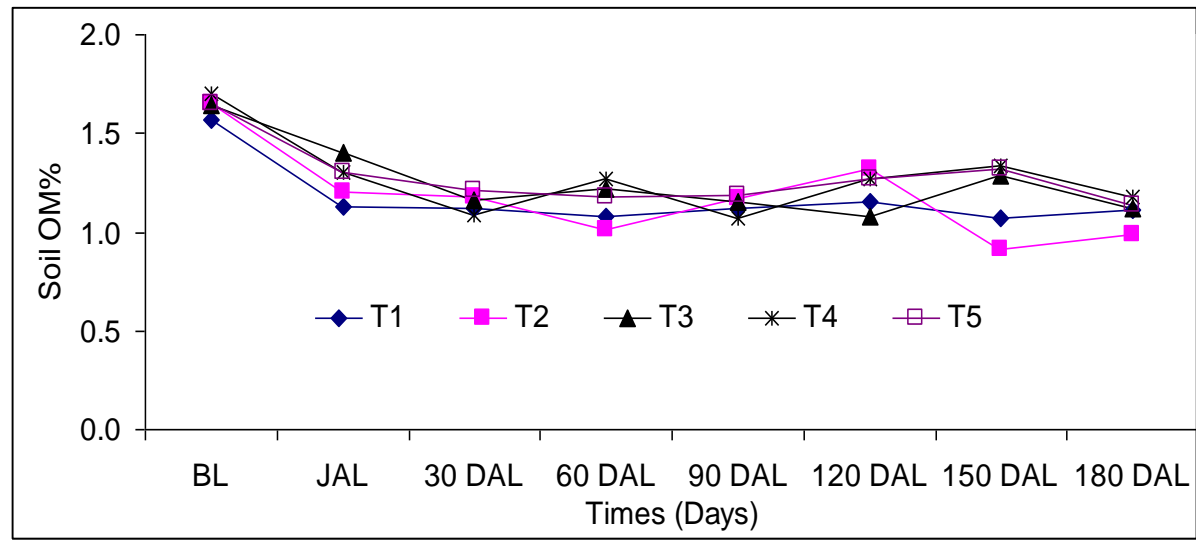

Figure 2. Soil OM status before liming and at different days after liming

\section{Total Nitrogen}

Figure 3 shows the total nitrogen in the tested soils collected from Mungbean field followed by T. Aman. The average total nitrogen content of initial soil was very low. After liming, at $30 \mathrm{DAL}$, the higher total nitrogen content was observed, this might be due to the higher soil $\mathrm{pH}$ increased the organic matter mineralization and microbial activity and fertilization for the crops. But considering 180 days, after liming the total nitrogen content in the study soil was not remarkably increased or reduced, i.e., the variation amongst the treatment was non-significant. But it was slightly increased at $150^{\text {th }}$ DAL, possibly due to the application of nitrogenous fertilizers for T. Aman crop. Because, the farm area was an irrigated and sandy loam soil and nitrogen content had lower than non-irrigated soils. This might be due to the leaching losses of $\mathrm{NO}_{3}-\mathrm{N}$, gaseous losses of nitrogen and also the deficiency of organic matter leading to shortage of nitrogen in the study area. Similar observations were also reported by Well et al., (1990) and Ritter (1989).

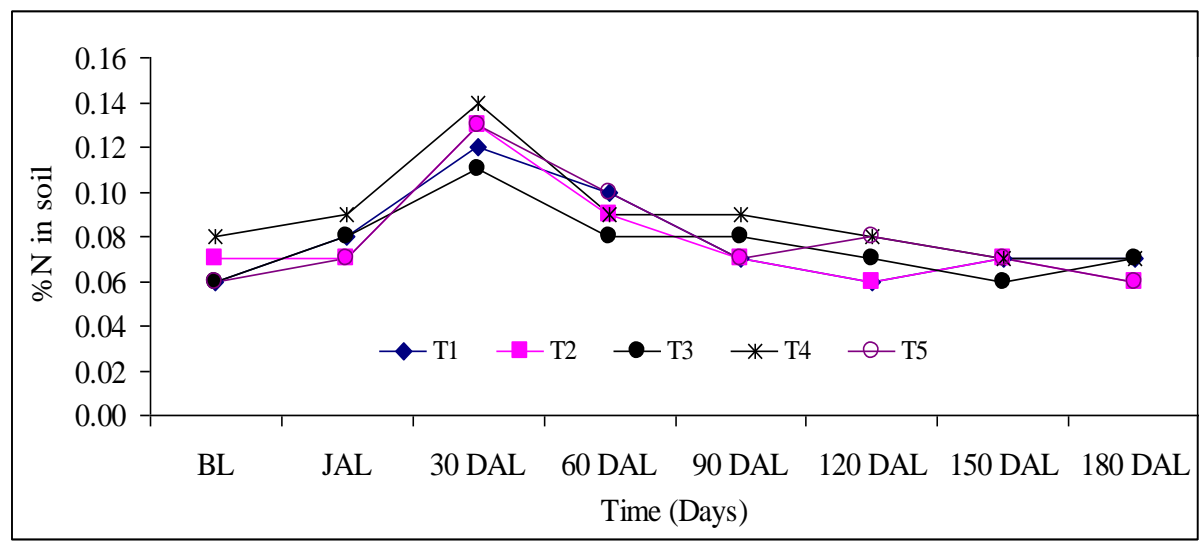

Figure 3. Soil $\mathrm{N}$ status before liming and at different days after liming

\section{Phosphorus}

The change of soil phosphorous was described in Figure 44. Initially, soil P was low but it started to increase just after liming. The result indicated that lime application increased $\mathrm{P}$ availability in the Mungbean followed by T. Aman field. The average phosphorus content in initial soil was lower than soils collected after liming. The $\mathrm{pH}$ of initial soil and soil before liming were below 6.0. But the $\mathrm{pH}$ of soils after liming were higher than 6.01. Where Bray and Kurtz' method was used for P determination, with ammonium fluoride $\left(\mathrm{NH}_{4} \mathrm{~F}\right)$ as extracting solution. The $\mathrm{pH}$ of soils that were collected after liming was greater than 6.0 where Olsen's method were used for P determination with sodium hydrogen carbonate solution as extracting solution. Ammonium fluoride extract more $\mathrm{P}$ even bound and fixed phosphorus form soil compared with sodium hydrogen carbonate solution. So, in lower $\mathrm{pH}$ the availability of $\mathrm{P}$ was slightly high than higher $\mathrm{pH}$ in the study area. The finding justifies the work done by Robert etal., (2005), there is no specific $\mathrm{pH}$ level that result in maximum $\mathrm{P}$ availability. Generally soil $\mathrm{pH}$ should be maintained 6.0 to 7.5 to maximize plant available P. Possibly the higher concentration of $\mathrm{P}$ was due to the application of phosphate fertilizer in acidic soil over time because $\mathrm{P}$ is not mobile. This result agreed to report of Clif et al., (1999), they found that P is not mobile in the soil and can result in high concentrations over time. 


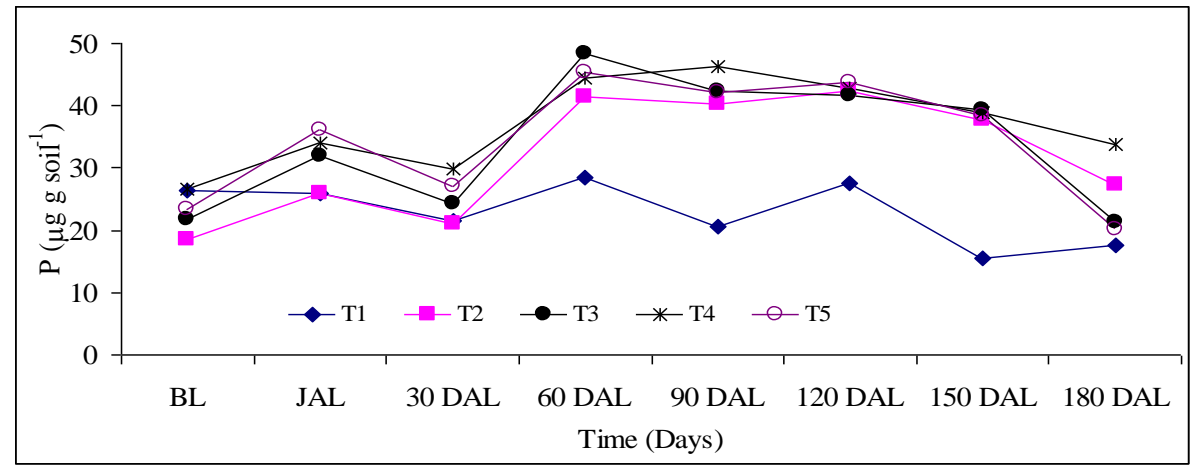

\section{Potassium}

Figure 4. Soil $\mathrm{P}$ status before liming and at different days after liming

The application of different levels of lime increased $\mathrm{K}$ availability of soils at just after liming but it began to decrease than those of initial status to the status that was at before liming (Figure 5). Significant variations among the treatments were observed. But better concentration of available $\mathrm{K}$ was obtained with treatment $\mathrm{T}_{4}\left(1.5 \mathrm{t} \mathrm{ha}^{-1}\right)$. Similar observations were reported by Culleton et al., (1999) and explained that the supply of exchangeable potassium in the soil is often low in acid soils, due to the formation of soluble $\mathrm{K}$ salt by acids soil and their loss by leaching from the soil. The availability of $\mathrm{K}$ begins to fall below a $\mathrm{pH}$ of 6.0 . This finding was also in coincided with the finding of Basak (2004) found that liming acid soils promotes potassium availability to plant.

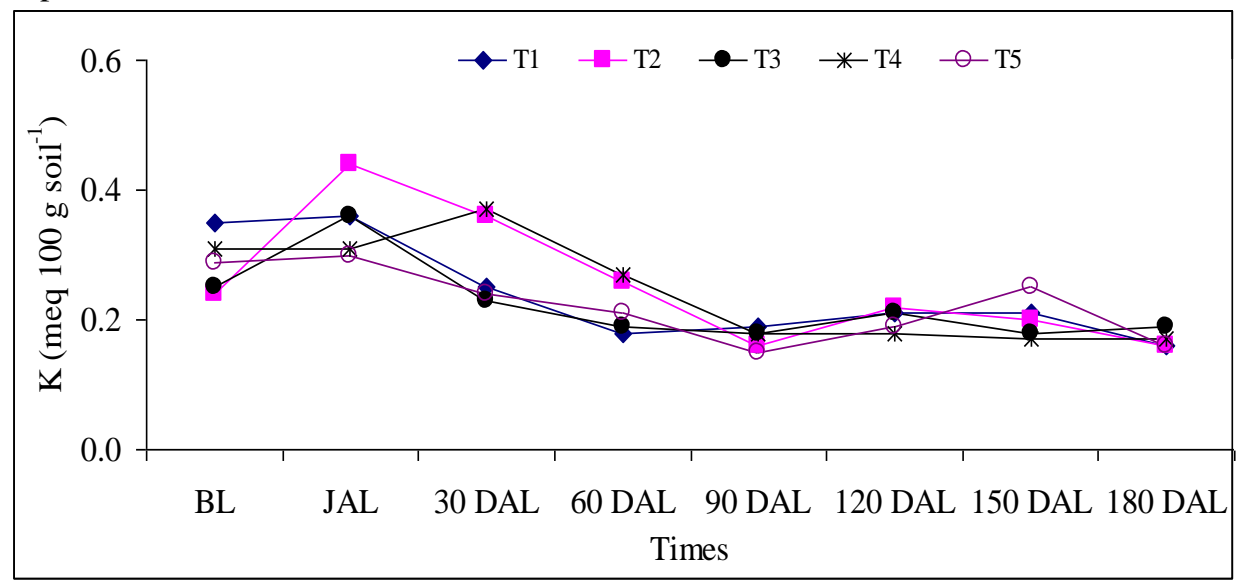

\section{Sulphur}

Figure 5. Soil K status before liming and at different days after liming

It is expected that liming will bring an increase in microbial activity and a decrease in the OM content in the soil (Curtin et al., 1998). Clif Little et al. (1999) reported that sulphur (S) is like nitrogen and its availability is greatly influenced by the activities of microorganisms. Soil pH that favors forage growth generally favors microbial activity and sulphur availability. Sulphur has great potential to leach along with many of the bases (calcium, magnesium and potassium), which leach out as sulfates.

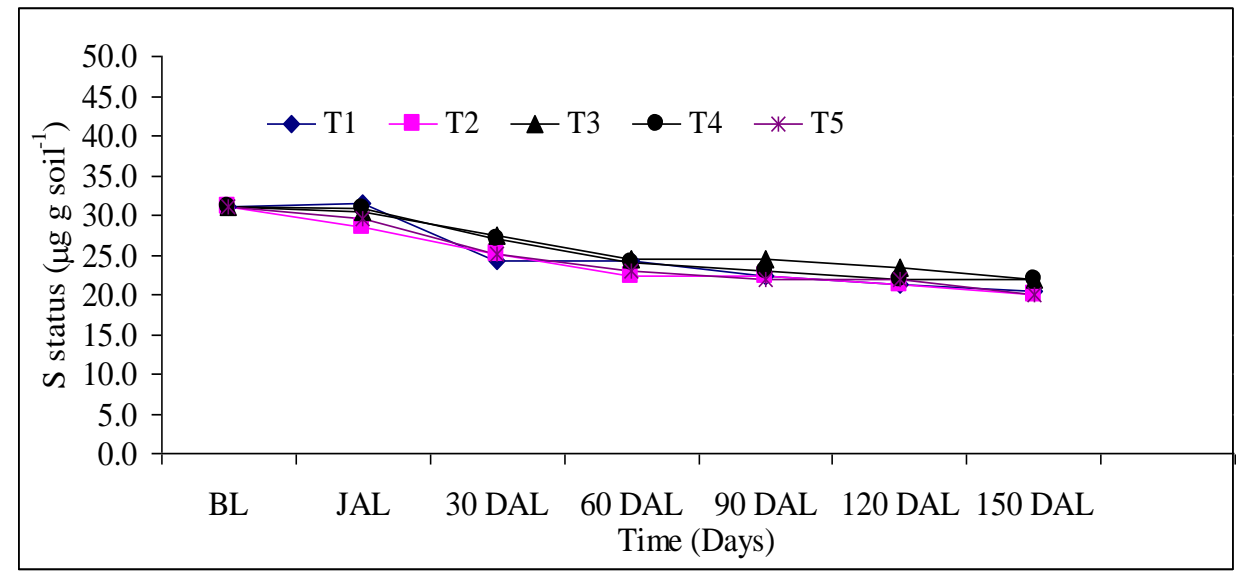

Figure 6. Soil S status before liming and at different days after liming 


\section{Calcium}

The status of calcium content in soil was presented in Figure 7. Available calcium in the sample that was collected different times of experiment showed the variable Ca content in soils. Just after liming Ca content increased sharply with the increased rates of lime application. The available $\mathrm{Ca}$ in the soil before liming was 2.22, 2.72, 2.6, 2.34 and 2.47 meq $100 \mathrm{~g} \mathrm{soil}^{-1}$ respectively, just after liming it showed a higher Ca content. The increasing trend was found up to 90 DAL. The liming material used as Dolochun [Dolomite, $\mathrm{CaMg}\left(\mathrm{CO}_{3}\right)_{2}$, which on dissolution released a large amount of $\mathrm{Ca}$ and thus the available $\mathrm{Ca}$ increased in soil after liming. The status of available $\mathrm{Ca}$ on soils was positively correlated with the rate of lime application, because application of lime increased the soil $\mathrm{pH}$, which increased available $\mathrm{Ca}$ in soil. The co-efficient of variation was $8.3 \%$ and that of LSD was 0.13 at $5 \%$ level of significant, which means a significant increased of Ca was obtained with lime application and the better concentration of $\mathrm{Ca}$ was observed with treatment $\mathrm{T}_{5}$. This result agreed to report of Garcia (1975) that the $\mathrm{pH}$ of acid soils increases due to liming, and adsorption is higher with higher rate of lime application and calcium deficiencies are ameliorated.Similar observations were also reported by Miller (2000) and Donahue, et al., (1981).

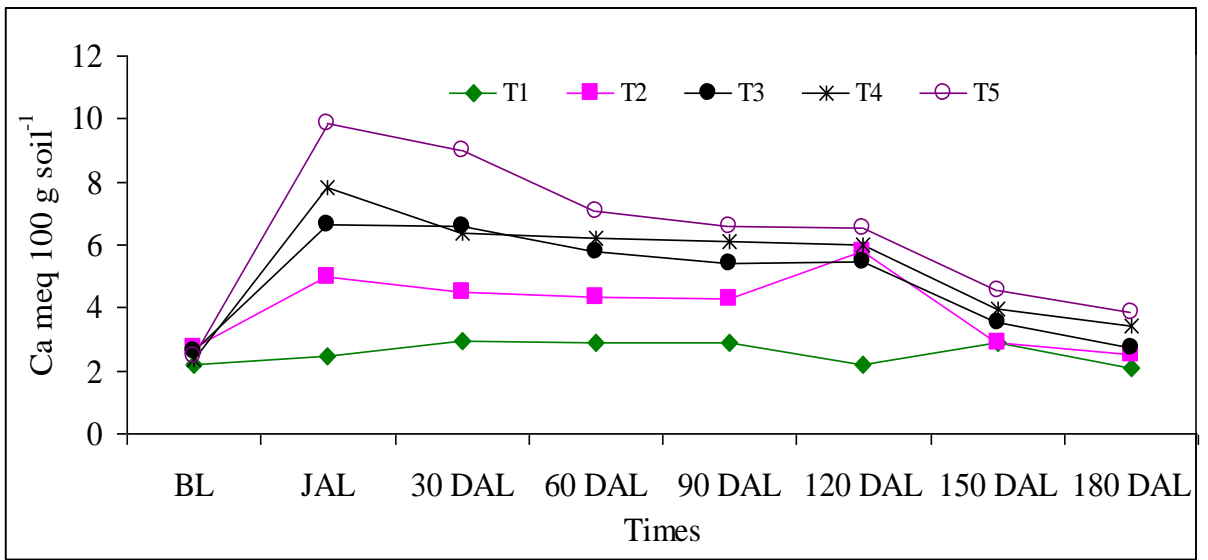

\section{Magnesium}

Figure 7. Soil Ca status before liming and at different days after liming

Available magnesium in soil samples collected at different times of experiment, were significantly variable. After liming, it increased gradually with increase rate of lime application (Figure 8). The content of available $\mathrm{Mg}$ in soil before liming was 0.63 and $0.7 \mathrm{meq} 100 / \mathrm{g}$ soil ${ }^{-1}$ which changed to $0.47,0.97,0.86,0.99$, and 1.12 meq 100/g soil ${ }^{-1}$ in $\mathrm{T}_{1}, \mathrm{~T}_{2}, \mathrm{~T}_{3}, \mathrm{~T}_{4}$, and $\mathrm{T}_{5}$, treatment respectively. The liming material used as Dolochun [Dolomite, $\mathrm{CaMg}\left(\mathrm{CO}_{3}\right)_{2}$ ], which on dissolution released a large amount of $\mathrm{Mg}$ that increased the $\mathrm{pH}$ of soils. The co-efficient of variation was 22.4 and LSD was 0.1 indicated a significant increase of $\mathrm{Mg}$ with lime application and the highest lime rate was more effective than lower rate. But, $\mathrm{T}_{5}$ was more statistically efficient. This finding was also in coincided with the finding of Garcia (1975). Similar observations were also reported by Miller (2000) and Donahue (1981).

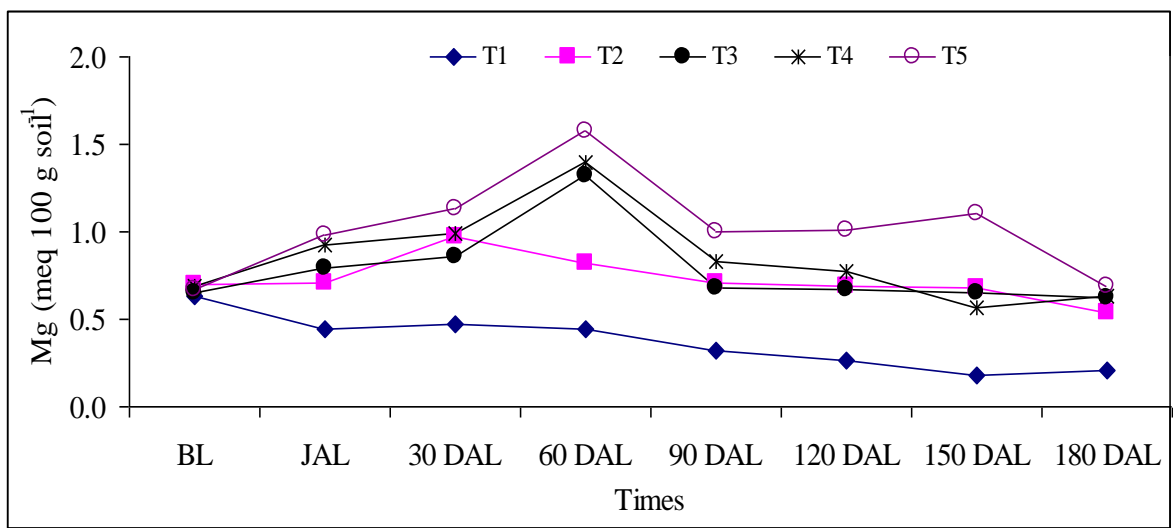

Figure 8. Soil Mg status before liming and at different days after liming

Zinc

The availably of $\mathrm{Zn}$ was slightly high in the initial soil and also in soil that collected before liming which decreased slightly after lime (Figure 9). The trend of decreased and increased availability of Zn was possibility 
due to increased $\mathrm{pH}$ after liming and decreased $\mathrm{pH}$ after application of nitrogenous fertilizer when $\mathrm{pH}$ decreased. Similar observation was also reported by Mikkelsen et al., (1994) that liming sandy acid soil availability of Zn decreased greatly by increased soil $\mathrm{pH}$.

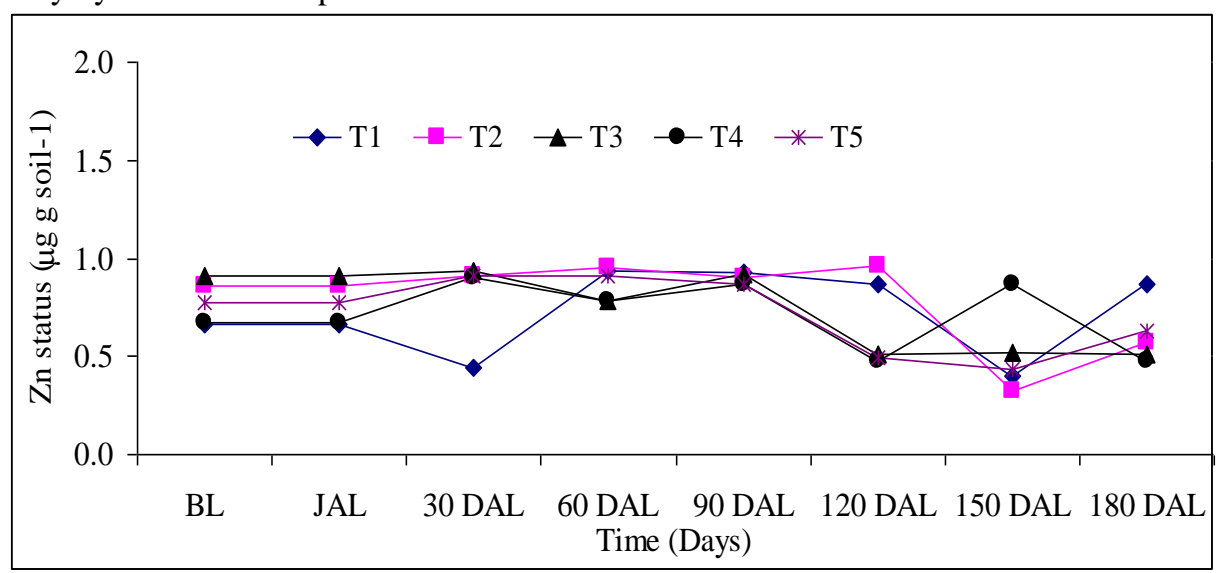

Figure 9. Soil Zn status before liming and at different days after liming

\section{Boron}

Available boron in the initial soil was $0.18 \mu \mathrm{g} \mathrm{g} \mathrm{soil}^{-1}$ which was below the critical limit $0.2 \mu \mathrm{g} \mathrm{g}$ soil ${ }^{-1}$ (BARC, 2005) which increased steadily with increased rate of lime application (Figure 10). The concentration of available $B$ in the soil samples that were collected after liming increased to $0.41,0.45,0.44,0.42$ and $0.82 \mu \mathrm{g}$ $\mathrm{g} \mathrm{soil}^{-1}$ in $\mathrm{T}_{1}, \mathrm{~T}_{2}, \mathrm{~T}_{3}, \mathrm{~T}_{4}$, and $\mathrm{T}_{5}$ treatment respectively. But better concentration of available $\mathrm{B}$ was obtained with treatment $\mathrm{T}_{5}$ and $\mathrm{T}_{4}$. Similar observations were also reported by Culleton et al., (1999) and Sultana et al., (2009).

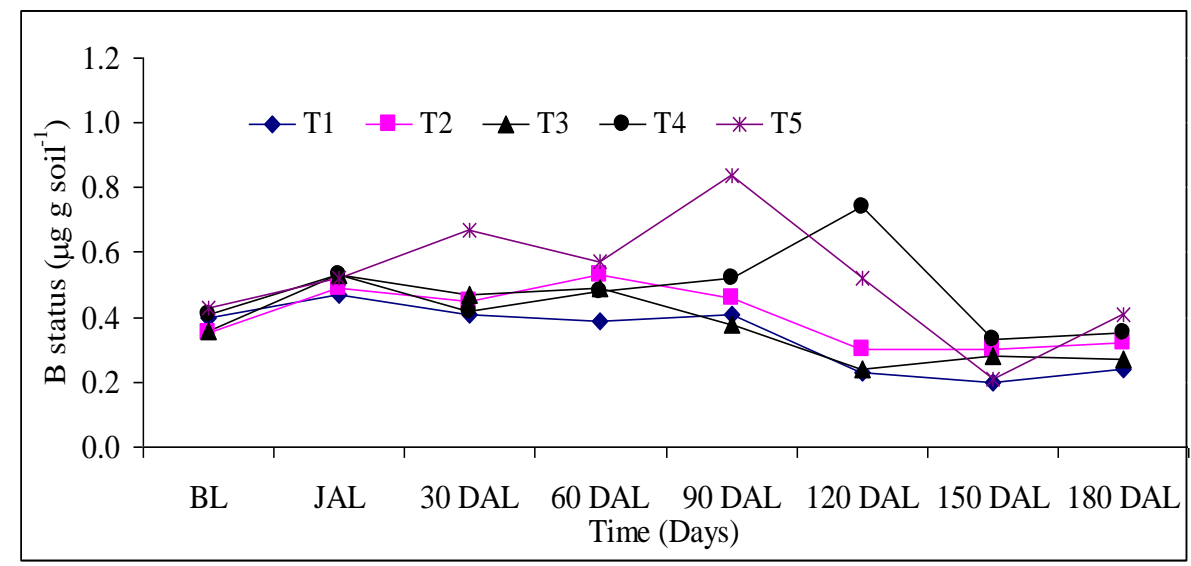

Figure 10. Soil B status before liming and at different days after liming

Iron

The iron concentration has been presented in Figure 11. The iron concentration in initial soil was 110.4 $\mu \mathrm{g} \mathrm{g}$ soil $^{-1}$ while as the critical limit and the upper limit of available iron is 4.0 and $>15.0 \mu \mathrm{g} \mathrm{g}$ soil $^{-1}$ (BARC, 2005). The concentration of $\mathrm{Fe}$ in the initial soil was excessively high but decreased with the increased rate of lime application to $91.87,128.37,74.49,58.338$, and $60.41, \mu \mathrm{g} \mathrm{soil}^{-1}$ in $\mathrm{T}_{1}, \mathrm{~T}_{2}, \mathrm{~T}_{3}, \mathrm{~T}_{4}$, and $\mathrm{T}_{5}$, respectively. On the other hand, $\mathrm{Fe}$ concentration decreased with increased rate of $\mathrm{pH}$ considering the $\mathrm{pH}$ of different rate of treatment as shown in Figure 11 and the highest availability of $\mathrm{Fe}$ was observed for treatment $\mathrm{T}_{5}$. It was justified with the explanation of BARC (2005). This findings was also supported by Luthra (1978), Gautom (1996) and Shamsuddin and Alextero (1991). 


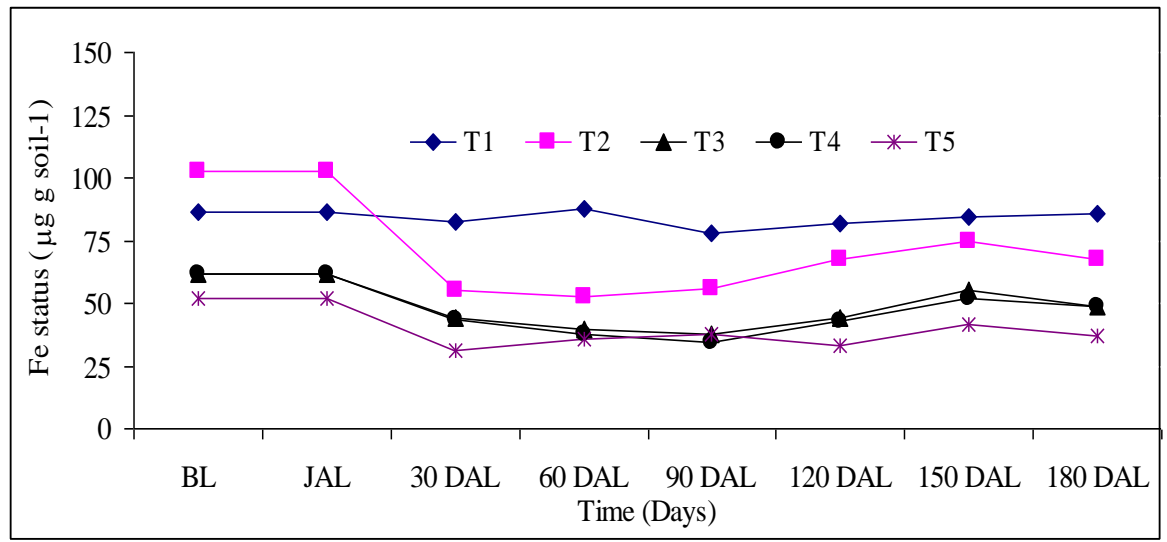

Figure 11. Soil Fe status before liming and at different days after liming

\section{Manganese}

Figure 12 shows the variable concentration in Mn during the study period. The manganese concentration was 0 to $0.3 \mu \mathrm{g} \mathrm{g}$ soil $^{-1}$ in initial soil, while the critical limit of $\mathrm{Mn}$ is $0.1 \mu \mathrm{g} \mathrm{g}$ soil $^{-1}$ (BARC, 2005). The availability of $\mathrm{Mn}$ increased with the increased value of $\mathrm{pH}$ up to below neutrality of soil and the concentration were $1.18,1.37,1.36,1.58,1.12$ and $0.83 \mu \mathrm{g}$ g soil ${ }^{-1}$ in $\mathrm{T}_{1}, \mathrm{~T}_{2}, \mathrm{~T}_{3}, \mathrm{~T}_{4}$ and $\mathrm{T}_{5}$, respectively. Therefore, the cause was the application of lime that increased the soil $\mathrm{pH}$ which helped the release of nonavailable $\mathrm{Mn}$ to available $\mathrm{Mn}$ for the treatment $\mathrm{T}_{5}$ where the $\mathrm{pH}$ range was below neutral range of soil. The highest value of $\mathrm{Mn}$ was observed at treatment $\mathrm{T}_{2}$ (Figure 12). It might be possibly due to the low $\mathrm{pH}$ of a mineral soil, when appreciable amounts of aluminum, manganese and iron were soluble. However, as the $\mathrm{pH}$ increased, precipitation takes place and the amounts of these ions in solution become less and less until at neutrality or somewhat above certain plants may suffer from a lack of available manganese and iron. This is especially true if a acidic sandy soil is suddenly brought to a neutral or alkaline condition by an excessive application of lime. This finding was also in coincided with the finding of Miller (2000) and Donahue (1981).

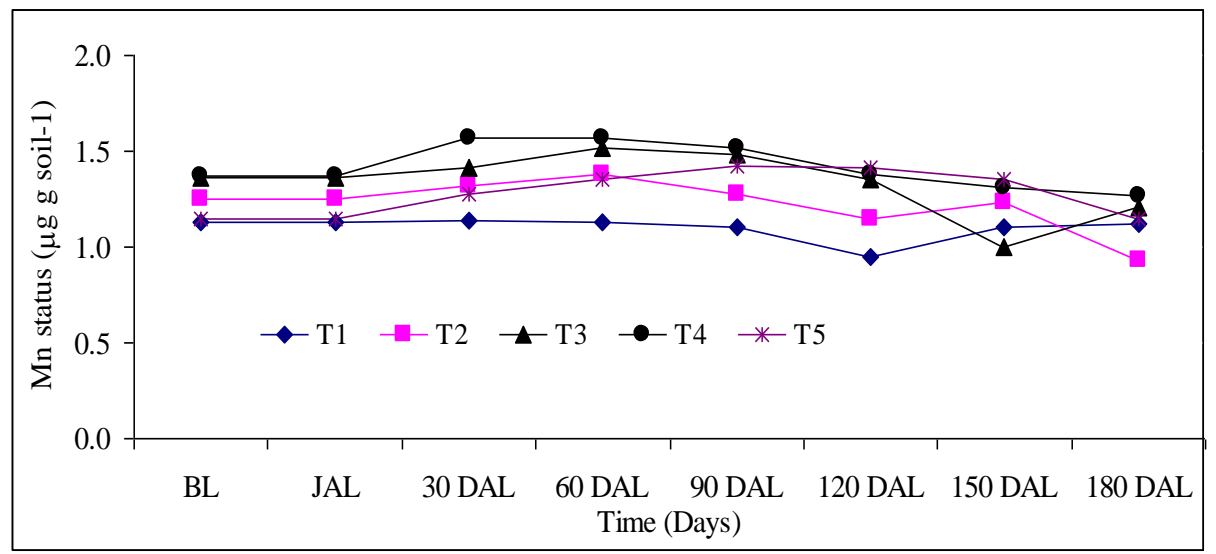

Figure 12. Soil Mn status before liming and at different days after liming

\section{Copper}

In the study area, initially the concentrate ion of $\mathrm{Cu}$ was at optimum range $0.42-0.53 \mu \mathrm{g} \mathrm{g}$ soil $^{-1}(0.45 /-$ $0.60 \mu \mathrm{g} \mathrm{gsil}^{-1}$ (FRG, 2005) and was steadily increased during first 30 days after liming, then slightly decreased up to 60th days as shown in Figure 13. Similar observation was also reported byWilliams at el., (2010) and finally slightly increased at higher level than initial status with time until 180 days of the experiment. Among the eight treatments the availability of $\mathrm{Cu}$ remain within the medium to vary high ranges $0.35-1.37 \mu \mathrm{g} \mathrm{g}$ soil $^{-1}$ with $\mathrm{T}_{4}$ trends was increasing after liming. This was agreed to the finding of that the availability of $\mathrm{Cu}$ would increased when the soil $\mathrm{pH}$ remain below 7.0 (Figure 13). 


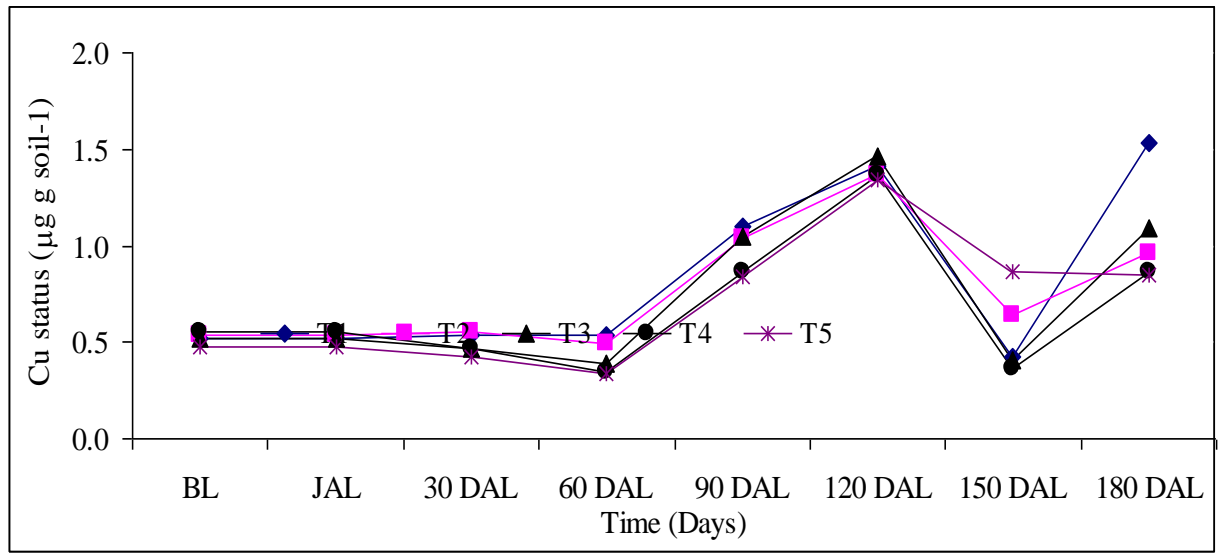

Figure 13. Soil $\mathrm{Cu}$ status before liming and at different days after liming

\section{Effect of liming on yield and yield contributing character of summer Mungbean}

\section{Number of pods plant ${ }^{-1}$}

Liming effect on number of pods plant ${ }^{-1}$ was found statistically highly significant (Table 1). The highest number of pods plant ${ }^{-1}$ (25.33) was found in $T_{3}$ higher than to that of $T_{1}, T_{2}, T_{4}$ and $T_{5}$. The lowest number of pods plant ${ }^{-1}(12.89)$ was found in $T_{1}$. The number of pods plant ${ }^{-1}$ was significantly influenced by the different treatments of lime application. The number of pods plant ${ }^{-1}$ by different treatment varied from 12.89 to 25.33. The highest number of pods was found in the treatment $T_{3}$. This is statistically superior to with $T_{5}, T_{1}, T_{2}$ and $T_{3}$ treatments. The treatments $T_{2}$ and $T_{3}$ were statistical identical in producing pods plant ${ }^{-1}$. The controlled plant showed the significantly lowest number of pods plant ${ }^{-1}$. The number of pods plant ${ }^{-1}$ of mungbean might be affected due to changes in soil properties in responses to liming. The results are similar to findings of Malik et al., (2006) and Mustary (2010).

Table 1. Effect of liming on yield and yield contributing character

\begin{tabular}{|c|c|c|c|}
\hline Treatment & No. of pods plant & & \\
& & No. of seeds pod $^{-1}$ & 1000 seeds weight $(\mathrm{g})$ \\
\hline $\mathrm{T}_{1}$ & 12.89 & 9.56 & 54.40 \\
$\mathrm{~T}_{2}$ & 15.67 & 9.89 & 53.89 \\
$\mathrm{~T}_{3}$ & 25.33 & 11.88 & 55.93 \\
$\mathrm{~T}_{4}$ & 24.67 & 11.67 & 54.33 \\
$\mathrm{~T}_{5}$ & 23.33 & 11.63 & 55.22 \\
$\mathrm{LSD}$ & 1.7 & 0.3 & 0.1 \\
$\mathrm{CV}(\%)$ & 7.25 & 7.25 & 5.15 \\
\hline
\end{tabular}

\section{Number of seeds pod ${ }^{-1}$}

Liming effect on number of seeds pod $^{-1}$ was found statistically highly significant (Table 1). The highest number of seeds $\operatorname{pod}^{-1}$ (11.67) was found in $T_{4}$ and similar to that of $T_{5}$. The lowest number of pods plant ${ }^{-1}(9.56)$ was found in $T_{1}$. The number of seeds pod ${ }^{-1}$ increased due to due to effect of different rates of lime. Seeds pod ${ }^{-1}$ ranged from 9.56 in $T_{1}$ to11.88 in $T_{4}$. The number of seeds pod ${ }^{-1}$ was found maximum in $T_{3}$ treatment which is seed statistically similar to $T_{4}$ and $T_{5}$. The treatment was superior to $T_{1}$ and $T_{2}$ in regard to number of seeds pod 1 . The number of seeds pod $^{-1}$ of mungbean was affected due to changes in soil properties due to liming. The result is in agreement with Sharma et al., (2000), they reported that limes application significantly increased yield of mungbean.

\section{0 seeds weight}

Liming had non-significant effect on the 1000 seeds weight of mungbean (Table 1). The 1000 seeds weight of mungbean varied from $53.89 \mathrm{~g}$ to $55.33 \mathrm{~g}$. The 1000 seeds grain weight for $\mathrm{T}_{3}$ was highest $(55.33 \mathrm{~g})$ and the lowest was in $\mathrm{T}_{2}(53.89 \mathrm{~g})$. The 1000 seeds weight and grain yield of mungbean was affected due to changes in soil properties due to liming. It appears that liming increased soil $\mathrm{pH}$ and availability of nutrients which increased the yield components of mungbean finally higher yields of mungbean. 


\section{Grain yield}

Liming effect on grain yield was found statistically highly significant (Figure 14). The highest grain yield $\left(1.58 \mathrm{t} \mathrm{ha}^{-1}\right)$ was found in $\mathrm{T}_{3}$ greater than that of other. The lowest number of grain yield $\left(1.16 \mathrm{t} \mathrm{ha}^{-1}\right)$ was found in $\mathrm{T}_{1}$. The rate of lime application $1.5 \mathrm{tha}^{-1}$ significantly increased the grain yield of mungbean compared to control. Application of lime improve seed yield of mungbean to a considerable extent but application of lime at the rate of $1500 \mathrm{~kg} \mathrm{ha}^{-1}$ was beneficial for higher yield of mungbean. This amount was in agreement with the recommendation of BARC (2005).

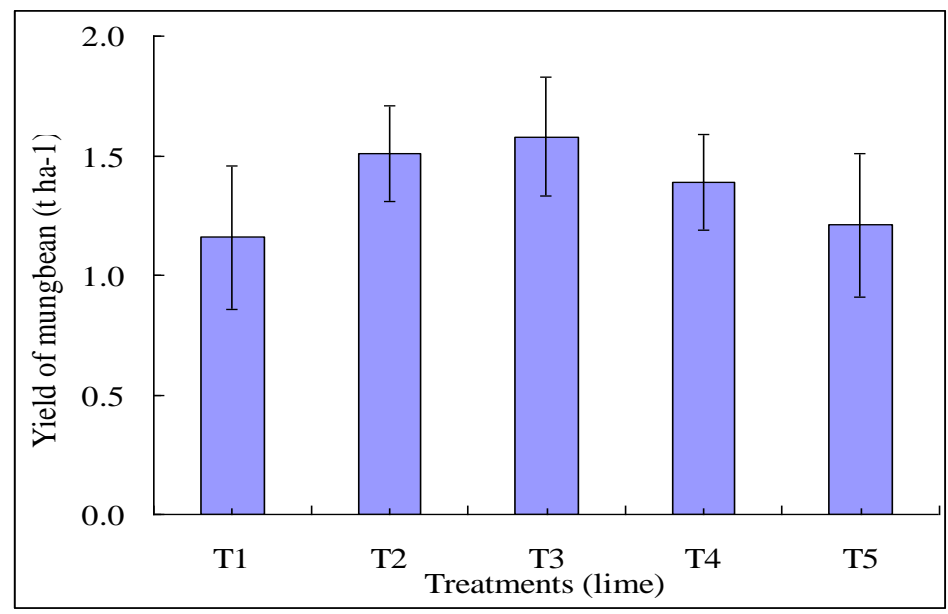

Figure 14. Effect of lime on yield of Mungbean

The grain yield of mungbean was affected by changing soil properties due to liming and growth regulator-NAA. It appears that liming increased soil due to $\mathrm{pH}$ and availability of nutrients which increased the yield components of mungbean resulted in higher yields of mungbean. Consequently, the yield of crop depends on genetic variation, soil, environment, proper management etc (FAO, 1998). So, the yield of Mungbean would be beneficial effect of lime application to soil.

\section{Summary and Conclusion}

This work evaluated the effect of liming in acid soil on the chemical changes, i.e, plant nutrient availability and yield of mungbean in Mungbean - T. Aman - Fallow cropping pattern.

The $\mathrm{pH}$ of the initial soil and soil before liming from different unit plot were steadily increased with the increased rate of liming. The $\mathrm{pH}$ of initial soil was 5.50 which increased up to 7.14 by the highest rate of lime application, i.e., T5 treatment. The soil organic matter decreased due to application of lime. After liming the total nitrogen content in the study soil was variable amongst the treatment was not significant. After liming, at 30 days, the higher amount of nitrogen content was observed, this might be due to the higher soil pH increased the organic matter mineralization and microbial activity and fertilization for the crops.

The result indicated that lime application increased the $\mathrm{P}$ availability in the Mungbean followed by $\mathrm{T}$. Aman field. The average phosphorus content in initial soil was lower than soils collected after liming. The $\mathrm{pH}$ of initial soil and soil before liming were below 6.0, but the $\mathrm{pH}$ of soils after liming tended to be higher than 6.01 . The higher concentration of $\mathrm{P}$ was due to the application of phosphate fertilizer in acidic soil over time because $\mathrm{P}$ is not mobile.

A significant variation among the treatments were observed foe $\mathrm{K}$ content in soil but higher concentration of available $\mathrm{K}$ was obtained with treatment $\mathrm{T}_{4}\left(1.5 \mathrm{tha}^{-1}\right)$. The supply of exchangeable potassium in the soil is low in acid soils, due to the formation of soluble K salt by acid soils and their loss by leaching from the soil. Sulpher content changes in the soil due to lime application were not significant. The effect is only addition.

Among the doses the highest value for each micro elements were obtained with treatment $T_{1}$ for Mn only; $T_{2}$ for $\mathrm{Fe}$ only; $\mathrm{T}_{4}$ for $\mathrm{K}, \mathrm{Mg}, \mathrm{N}, \mathrm{S}, \mathrm{B}$, and $\mathrm{Cu} ; \mathrm{T}_{5}$ for $\mathrm{Zn}$ only; $\mathrm{T}_{4}$ for $\mathrm{Ca} \& \mathrm{P}$ only and $\mathrm{T}_{5}$ for $\mathrm{pH} \& \mathrm{OM}$ only. On the other hand, the smallest value were obtained in $\mathrm{T}_{1}$ for $\mathrm{pH}, \mathrm{OM}, \mathrm{Ca}$, and $\mathrm{Mg} ; \mathrm{T}_{5}$ for $\mathrm{Cu}$ only; $\mathrm{T} 4$ for $\mathrm{S} \& \mathrm{Zn}$ only and $\mathrm{T}_{5}$ for $\mathrm{K}, \mathrm{N}, \mathrm{P}, \mathrm{B}, \mathrm{Fe}$ and $\mathrm{Mn}$. 
A significant and positive correlation between the $\mathrm{pH}$ status and available $\mathrm{Ca}, \mathrm{Mg}$ and $\mathrm{B}$ was observed with increased rate of lime application. The treatment $\mathrm{T}_{3}$ showed better where $\mathrm{pH}$ value changed from 5.82 to 7.1 and supply more available plant nutrients by increasing the concentration of $\mathrm{K}, \mathrm{Ca}, \mathrm{Mg}, \mathrm{N}, \mathrm{P}, \mathrm{S}, \mathrm{B}, \mathrm{Cu}$ and $\mathrm{Mn}$. Though, with treatment $\mathrm{T}_{4}$, the content of $\mathrm{OM}$ and soil $\mathrm{Zn}$ decreased slightly along with the excessive concentration of $\mathrm{Fe}$ decreased slightly and lowered within the range of optimum to very high interpreted level. From the above discussion treatment $\mathrm{T}_{3}$ i.e., liming with $1.5 \mathrm{t} \mathrm{ha}^{-1}$, total content of available nutrients was increased. The different yield attributing characters of mungbean were significantly increased by the application of lime. The application of $1.5 \mathrm{t} \mathrm{lime} \mathrm{ha}{ }^{1}$ significantly increased the yield of summer Mungbean compared to control.

The highest grain yield was found in $\mathrm{T}_{3}\left(1.50 \mathrm{t} \mathrm{h}^{-1}\right)$, which was statistically identical with the grain yields obtained in $\mathrm{T}_{4}$, treatments but superior to those found in $\mathrm{T}_{1}, \mathrm{~T}_{2}$ treatments. Thus, the application of $1.5 \mathrm{t}$ lime ha ${ }^{1}$ is beneficial for higher yield of summer Mungbean. Thus, the application of $1.5 \mathrm{t}$ lime ha ${ }^{-1}$ appears to be optimum for desired soil $\mathrm{pH}(>6.5$ but $<7.0)$ which increased availability of nutrient and ultimately increased yield of mungbean.

In conclusion, for the acidic soils of North West Bangladesh, 1.5 ton $\mathrm{h}^{-1}$ of lime application is beneficial to sustain high yield. Thus, liming may be an important management practice to tailoring the soil to meet plant needs by improving the soil $\mathrm{pH}$ that increases the availability of plant nutrients and can play major roll in yielding potentials to plant.

\section{References}

[1]. Adams F. 1980. Soil Acidity and Liming, Crop response to lime in the western United States, Madison, Wisconsin, USA.

[2]. FRG (Fertilization Recommendation Guide). 2005. Bangladesh Agricultural Research Council (BARC), Bangladesh.

[3]. SRDI (Soil Resource Development Institute), Soil and Land Utilization Guide (Upazila Nirdeshika).2008. Birol Upazila, Dinajpur District, MOA, Dhaka.

[4]. Karim Z and Anwar I. 2001. Impact of Land Degradation in Bangladesh, BARC (Bangladesh Agricultural Research Council) Farmgate, Dhaka.

[5]. Arshad MA, Gill KS, Turkington TK and Woods DL.1997. Canola root and yield response to liming and tillage. Agron. J. 89: 1722.

[6]. Maschner H. 1991. Mechanisms of adoption of plant to acid soil. J. Plant Sci. 134:1-20.

[7]. Edmeades DC, Blamey FPC and Farina MPW. 1995. Techniques for assessing plant response on acid soils. P, 221-233. In R.A. Dete. Plant soil interactions at low pH: Principles and Management. Kluwer Acad. Publ. Dordrecht. The Netherlands.

[8]. Alva AK, Edwards DG, Asher CJ and Suthipradit S. 1987. Effects of acid soil infertility factors on growth and nodulation of soybean. Agron. J. 79: 302-306.

[9]. Ocampo AM. 2000. Screening procedures for tolerance to marginal soils. University Researcher. IPB, UPLB.

[10]. Sahai VN. 1990. Fundamental of Soil Science. Kalyani Publishers, Ludhiana, New Delhi. 76-84.

[11]. UNDP and FAO. 1988. Land Resources Appraisal of Bangladesh for Agricultural Development. Report 2, Agroecological Regions of Bangladesh. UN Dev. Prog. Food and Agric. Org.: 212-221.

[12]. Buoyoucos GJ. 1927. Hydrometer method improved for making particle size analysis of soils. Agron. J. 54: 4661-4665.

[13]. Jackson ML. 1962. Soil Chemical Analysis. Prentice Hall of India Pvt. Ltd. New Delhi. pp. 10-14.

[14]. Page AL, Miller RH and Keeny DR. 1982. Methods of Soil Analysis. Part-I and Part-II. $2^{\text {nd }}$ Ed. Ani. Soc. Agron. Inc. Madi., Wis., USA.

[15]. Petersen L. 1999. Soil Analytical Methods. Soil Testing, Management and Development of SRDI Project. Soil Resource Development Institute, Danida Kampsax, Dhaka.

[16]. Piper CS. 1950. Soil and Plant Analysis. Adelaide Univ. Hasel press. Australia.

[17]. Rao BKS, Panchaksharjah Patil BN, Narayana A and. Raiker DIS. 1982. Chemical composition of irrigation waters, from selected parts of Bijaypur district, Kamataka. Msore Journal of agricultural Science 16(4): 426-432.

[18]. Basak B. 2010. Nutrient dynamics and chemical properties of acid soil under different liming condition. MS thesis, Department of Agricultural Chemistry, Hajee Mohammad Danesh Science and Technology University, Dinajpur.

[19]. Murali NS. 1976. Effect of lime, phosphorus and nitrogen on the growth, yield and chemical composition of soybean. M. Sc. Thesis No. 991. AIT, Bangkok, Thailand.

[20]. Curtin D, Campell CA, Jalil A. 1998. Effects of acidity on mineralization: pH-dependence of organic matter mineralization in weakly acidic soils. Soil Biology \& Biochemistry, v.30, p.57-64.

[21]. Renato Y, Ferreira ME, Cristina M, Cruz P and Burbosa JC. 2003. Organic matter fractions and soil fertility under influence of liming, vermi compost and cattle manure, Sci. agric. vol.60: 3, Piracicaba, Soil and Plant nutrition.)

[22]. Kreutzer K. 1995. Effects of forest liming on soil processes. Plant and Soil, v.-168-169, p.447-470.

[23]. Well RR, Turner WRS. 1990. Nitrate contamination of ground water under irrigated coastal plain soils. Journal of Environmental Quality.19 (3):44-448.

[24]. Ritter WF. 1989. Nitrate leaching under irrigation in United States. A review. J. Environ. Sci. Health. Part A. 24(4):349-378.

[25]. Robert MEL and Watson M. 2005. Ohio Agronomy guide, $14^{\text {th }}$ edition Bulletin 472-05, chapter 3, Soil fertility.

[26]. Clif L and McCutcheon J. 1999. Fertility Management of Meadows, Agriculture and Natural Resources, Ohio State University Extension Fact Sheet, 2120 Fyffe Road, Columbus, Ohio :43210-1084

[27]. Culleton N, Murphy WE and. Coulter B. 1993. Lime in Irish Agriculture, The Fertilizers Association Ireland, Publication, Teagasc, Johnstown Castle, Co. Wexford.

[28]. Basak. 204. Textbook of Fertilizers. $3^{\text {rd }}$ edition, Kalyani Publisher, New Delhi-110002.

[29]. Miller PR. 2000. Effect of varying seeding date on crop development, yield and yield components in canary seed. Canadian J. Plant Sci. 80(1): 83-86. 
[30]. Donahue RL, Follett RH and Murphy LS. 1981. Fertilizer and Soil Amendments. Chapter 4. Prentice-Hall Inc., Englewood Cliffs, New Jersey 07632, USA. P197, p170.

[31]. Garica FV. 1975. Depth of liming on very acid soils. M. Sc. Thesis No. 842 AIT, Bangkok, Thailand.

[32]. Mikkelsen and Camberato 1994. Use of Potassium, Sulfur, Lime, and Micronutrients. Nutrient Management, Institute of Food and Agricultural Science, University of Florida,

[33]. Sultana BS, Miah MMH, Islam MR, Rahman MM, Sarker BC and Zoha MS. 2009. Effect of liming on soil properties, yield and nutrient uptake by wheat. Current world environment. 4(1): 39-47

[34]. Gautam AK. 1996. Effects of lime and phosphate on mungbean and groundnut in irrigated acid sulphate soils. M Sc, Thesis No. AE-96-37, AIT, Bangkok, Thailand.

[35]. BARC (Bangladesh Agricultural Research Council), 2005. Fertilizer Recommendation Guide-2005. Soil Pub. No.45, Farmgate, Dhaka.

[36]. Luthra VK. 1978. Liming and leaching of acid sulphate soils, M. Sc. Thesis No. AE-78-3, AIT, Bangkok, Thailand

[37]. Shamsuddin J and Auxtero EA. 1991. Soil solution compositions and mineralogy of some active acid sulphate soils in Malaysia as affected by laboratory incubation with lime. Soil Science, 152(5): 365-376.

[38]. Williams A and Lucio R. 2010, Copper availability as related to soil copper fraction in Oxisols under liming.

[39]. Malik MA, Irfan M, Ahmed ZI, Zahoor F. 2006. Residual effect of summer grain legumes on yield and yield components of wheat (Triticumaestivum L.). Pakistan. J. Agric, -Sci. Vol. 22(1): 9-11

[40]. Mustary S. 2010. Effect Of Different Liming Conditions On Root Growth, Yield and Protein Content Of Summer Mungbean. Unpublished MS Thesis. Department of Agricultural Chemistry Hajee Mohammad Danesh Science and Technology University, Dinajpur.

[41]. Sharma SN, Prasad Singh R and Singh SP. 2000. On-farm trials of the effect of introducing a summer green manure of mungbean on the productivity of a rice-wheat cropping system. J. Agric. Sci. Vol: 134(2) 169-172

[42]. Food and Agricultural Organization. 1998. Selected Indicator of Food and Agriculture Development in Asia Pacific Region. RAPA Publication, FAO, Bangkok, Thailand. 